\title{
PENGELOLAAN PEMBELAJARAN TEMATIK DI SD NEGERI 4 PURWODADI GROBOGAN
}

\author{
Sutipah \\ SD N 1 Candisari Purwodadi Grobogan \\ Sutipah.1candisari@gmail.com
}

\begin{abstract}
The purpose of this research was to describe: (1) thematic learning planning. (2) the implementation of thematic learning, and (3) thematic learning evaluation in SD Negeri 4 Purwodadi sub-district of Purwodadi Grobogan 2016/2017. The method used is qualitative method.The source of the data in this study are students, teachers and principals trough observation, in -depth interviews and documentation.Data analysis data reduction at doing. The validity of the data using triangular source research rosults include the management of the thematic learning planning, implementation, and evaluation of thematic learning. Planning made teachers include : a)Education calender (kaldik), b) The preparation of the annual programme, c) preparation of semester,d) Syllabus and RPP (lesson plan) include: a) Introduction,b) core aktivities, and c) the activities cover the implementation of the evaluation: a) were in accordance with the principle-of normatif,b) has fulfilled the technically, c) Refers of the standard management. Engineering knowledge assessment test, writing instrument: description. Test result of 49 students who complete IPA 45 students $91.84 \%$ avarage value of 83.57 , Indonesian language mastery 43 students $87.76 \%$ of the average value of 89.90 and Mathematics 42 students thoroughly $85.71 \%$ of the average value 72.04. Assessment of the spiritual and social attitudes. Indicators of assessment of the attitude is cooperation. an average of 3.5 in category A (very good). Enginnering skills assessment the is a form of non test instrument of observation and assessment rubric sheet average 83.25 category B (good)
\end{abstract}

Keywords: management, learning, thematic

\begin{abstract}
Abstrak. Tujuan penelitian ini untuk mendeskripsikan : (1) perencanaan pembelajaran tematik, (2) pelaksanaan pembelajaran tematik. (3) Evaluasi pembelajaran tematikdi SD Negeri 4 Purwodadi Kecamatan Purwodadi Kabupaten Grobogan tahun 2016/2017. Metode yang digunakan adalah metode kualitatif. Sumber data dalam penelitian ini siswa, guru dan kepala sekolah melalui observasi, wawancara yang mendalam dan dokumentasi. Analisis data dilakukan resduksi data. Keabsahan data menggunakan Triangulasi sumber. Hasil penelitian meliputi pengelolaan pembelajaran tematik, pelaksanaan pembelajaran tematik, dan evaluasi pembelajaran tematik. Perencanaan yang dibuat guru meliputi : a) kaldik (kalender pendidikan), b) Penyusunan PROTA (Program tahunan), c) Penyusunan Promes (Program Semesrter ), d ) Silabus dan RPP (Rencana Pelaksanaan Pembelajaran) meliputi: a) Pendahuluan, b) Kegiatan Inti, dan c) Kegiatan Penutup. Pelaksanaan Evaluasi: a) telah sesuai dengan prinsip-prinsip normative, b) telah memenuhi secara teknis, c) mengacu pada tandar pengelolaan. Penilaian pengetahuan: teknis tes, bentuk tertulis, instrument Uraian. Hasil tes dari 49 siswa yang tuntas IPA 45 siswa 91,84\% rata-rata nilai 83,57, Bahasa Indonesia tuntas 43 siswa $87,76 \%$ rata-rata nilai 83,90 dan matematika 42 siswa tuntas $85,71 \%$ ratarata nilai 72,04. Indikator penilaian sikap adalah kerjasama. Rata-rata 3,5 dalam kategori A (sangat baik ). Penilaian keterampilan: Teknik non tes, bentuk unjuk kerja, instrument lembar observvasi dan rubrik penilaian rata-rata 83,25 kategori B (baik )
\end{abstract}

Kata kunci: pengelolaan ,pembelajaran,tematik 


\section{Pendahuluan}

Pembelajaran tematik kurikulum 2013 di SD Negeri 4 Purwodadi Kecamatan Purwodadi Kabupaten Grobogan dimulai sejak Semester II Tahun Pelajaran 2014/2015 kemudian kembali menggunakan Kurikulum KTSP 2006 selama 1 Tahun Pelajaran (2 Semester) yaitu pada Tahun Pelajaran 2015/2016 selanjutnya pada Tahun Pelajaran 2016/2017 kembali menerapkan Kurikulum 2013 selama 1 Tahun Pelajaran (2 Semester) dan sampai saat ini Tahun Pelajaran 2017/2018 semester 1 SD Negeri 4 Purwodadi Kecamatan Purwodadi Kabupaten Grobogan tetap menerapkan Kurikulum 2013.

Pembelajaran tematik di SD Negeri 4 Purwodadi memiliki permasalahan. Permasalahan atau kendala dibedakan menjadi tiga yaitu pada perencanaan, kendala pelaksanaan, dan kendala evaluasi. Agar lebih efektif, efisien, terarah dan dapat dikaji lebih mendalam maka dalam penelitian ini hanya mengkaji pembelajaran tematik kurikulum 2013 tema 8 Ekosistem, peneliti akan mengkaji tentang penelitian yang berjudul "Pengelolaanpembelajarantematikdi SD Negeri 4Purwodadikecamatan Purwodadikabupaten Grobogan

Dee L. Fabry (2010) dalam penelitiannya yang bertujuan mengungkap alasan siswa yang mengalami drop-out sekolah. Hasil penelitian menunjukkan peserta didik yang drop-out sekolah karena kurangnya relevansi pelajaran di sekolah, kebosanan akibat pembelajaran yang kurang sesuai dengan kebutuhan dan kondisi siswa. Penelitian ini mampu menjadi solusi untuk meningkatkan ketertarikan siswa bersekolah, dan mengurangi angka drop-out sekolah. Solusinya dengan pembelajaran kolaboratif antara guru dan siswa, memahami hubungan yang efektif antara guru dan siswa, serta pembelajaran yang menyenangkan untuk menyelesaikan jenjang pendidikannya.

Abdullah (2013) dalam penelitiannya menjelaskan pendekatan tematik. Penelitian mengidentifikasi pemahaman dan praktik yang dilakukan para guru terhadap pendekatan tematik menggunakan istrumen kuisioner. Penelitian ini menemukan bahwa ada hubungan signifikan antara tingkat pemahaman guru dengan pendekatan tematik yang dilakukan guru secara konstan dan terusmenerus. Semakin banyak pemahaman guru mengenai proses pembelajaran tematik, maka semakin baik penyampaian dan pemahaman guru dalam berkomunikasi dengan siswa di kelas.

Yvonne (2015) Penelitian ini tentang mengimplementasikan kurikulum baru terintegrasi. Temuan penelitian ini mengungkapkan pembelajaran tematik terintegrasi mampu memenuhi kebutuhan lebih efektif tidak menerapkan model pembelajaran tematik dan terintegrasi.

Hendra Jati Puspita (2016)Penelitian ini bertujuan untuk mendeskripsikan perencanaan, pelaksanaan, dan penilaian pembelajaran tematik terpadu. Penelitian ini merupakan penelitian deskriptif kualitatif. Hasil penelitian menunjukkan bahwa perencanaan tematik terpadu yang dilakukan guru sudah memuat kriteria minimal perencanaan pembelajaran. Pelaksanaan pembelajaran sudah memunculkan karakteristik pembelajaran tematik terpadu dan pendekatan saintifik sudah dilaksanakan.

Hayati (2012) Penelitian ini bertujuan untuk mendeskripsikanperencanaan, pelaksanaan dan evaluasi pembelajaran tematik terpadu. Hasil penelitian menunjukkan dalam perencanaan telah menyusun (RPP) dengan media yang disesuaikandengan kebutuhan sekolah, dalam pelaksanaan telah sesuai dengan RPP dan karakter siswa sesuai dengan kearifan localdan dalam evaluasi model evaluasi alat tes dan non tes secara terus-menerus yang digunakansebagai masukan guru mengambil keputusan terhadap siswa.

Depdiknas (2006:5) menyatakan bahwa,"pembelajaran tematik pada dasarnya merupakan model dari kurikulum terpadu yang menggunakan tema untuk mengaitkan beberapa mata pelajaran sehingga dapat 
memberikan pengalaman bermakna kepada peserta didik." Majid (2013:86) mengemukakan bahwa,"pembelajaran tematik adalah suatu pendekatan pembelajaran yang menghubungkan berbagai mata pelajaran yang mencerminkan dunia nyata di lingkungan siswa dan dalam rentang potensi, serta perkembangan anak."

Majid (2013:86 ) menyatakan bahwa,"Pembelajaran Tematik adalah suatu pendekatan pembelajaran yang menghubungkan berbagai bidang studi yang mencerminkan dunia nyata diskeliling siswa dan dalam rentang kemampuan,serta perkembangan anak.Pembelajaran tematik dalam kegiatannya meliputi perencanaan, pelaksanaan dan evaluasi. Perencanaan, pelaksanaan dan evaluasi pembelajaran tematik kurikulum 2013.

Menurut Muslich (2007:67), komponen terpenting pada perencanaan pembelajaran diarahkan pada lima aspek,yaitu a) perumusan tujuan pembelajaran. b) pemilihan dan pengorganisasian materi ajar. c) pemilihan sumber belajar/media pembelajaran. d) skenario/kegiatan pembelajaran, e) penilaian hasil belajar .

Pelaksanaan pembelajaran meliputi kegiatan pendahuluan,kegiatan inti,dan kegiatan penutup (Sanjaya,W,2006:41) Adapun kegiatan pembelajaran sebagai berikut pembelajaran diawali dengan kegiatan membuka yang bertujuan menarik perhatian siswa, menumbuhkan motivasi belajar siswa dan memberikan acuan atau ramburambu pembelajaran yang akan dilakukan. selanjutnya kegiatan yang dilakukan yaitu kegiatan pendahuluan, kegiatan inti dan kegiatan penutup.

Hajar (2013:267 )menjelaskan bahwa penilaian pembelajaran tematik adalah usaha yang dilkukan oleh pihak sekolah atau para guru untuk mendapatkan berbagai informasi secara berkala,berkesinambungan,dan menyeluruh tentang proses dan hasil dari pertumbuhan dan perkembangan yang telah dicapai oleh para peserta didik.
Akbar (2007:17) menjelaskan tentang teknik evaluasi pada pembelajaran terpadu hendaknya bersifat komprehensif yaitu meliputi proses dan hasilpembelajaran tematik dengan menggunakan teknik tes maupun non tes. Pada pembelajaran tematik diperoleh nilai pengetahuan, ketrampilan dan sikap.

\section{Metode}

Metode penelitian yang digunakan dalam penelitian ini adalah metode kualitatif. Sugiyono (2016:8) mengemukakan bahwa MetodePenelitian kualitatif sering disebut metode penelitian naturallistik karena penelitiannya dilakukan pada kondisi yang alamiah (natural setting ). Untuk mencari dan menemukan pengertian atau pemahaman tentang pengelolaan pembelajaran tematik di SD N 4 Purwodadi kec.Purwodadi kab. Grobogan.

Penelitian ini dilaksanakan di SD N 4 Purwodadi kec.Purwodadi kab.Grobogan Jl jend Sudirman No 10 Purwodadi. Waktu penelitian .Waktu penelitian dilaksanakan selama 7 bulan mulai bulan April 2016 sampai November 2017. Subjek dalam penelitian ini yaitu guru, siswa dan kepala sekolah. Desain penelitian ini menggunakan penelitian etnografi artinya dalam suatu pengkajian didasarkan pada pandangan bahwa budaya merupakan keseluruhan yang tidak dapat dipisahkan. Teknik Pengumpulan Data menggunakan Wawancara mendalam,Observasi ,dan dokumentasi. Keabsahan data yang digunakan dalam pengujian kredibilitas yaitu Triangulasi sumber,triangulasi teknik, Triangulasi waktu. Analisis data penelitian ini menggunakan reduksi data. Dalam melakukan analisis data mengacu kepada tahapan yang dijelaskan Milles dan Huberman (2007 :16) yaitu: (1) proses reduksi data (data reduction), (2) penyajian data (data display) dan (3) penarikan kesimpulan atau verifikasi (conclusion drawing/verivication). 
Hasil dan Pembahasan

1. Perencanaan Pembelajaran Tematik Kelas V di SD Negeri 4 Purwodadi Kecamatan Purwodadi Kabupaten Grobogan.

Kegiatan menyusun perencanaan pembelajaran sesuai dengan silabus kalender pendidikan, program tahunan, program semester, tujuan pembelajarandan alokasi waktu. Langkah menyusun perencanaan pembelajaran tematik, guru SD Negeri 4 Purwodadi kec. Purwodadi kab.Grobogan koordinasi dengan kegiatan kelompok Kerja Guru (KKG Dabin).Kegiatan tersebut diharapkan mampu menindak lanjuti terkait dengan masalah yang muncul dari pelaksanaan pembelajaran di Sekolah SD Negeri 4 Purwodadi.Kegiatan KKG membahas tentang penyusunan perencanaan pembelajaran tematik pelaksanaan pembelajaran tematik,dan evaluasi pembelajaran Tematik.

Langkah-langkah menyusun perangkat pembelajaran guru di dabin meliputi: Menyediakan bahan baku seperti Silabus,Buku-buku materi pelajaran atau buku guru dan buku siswa,model-model pembelajaran yang dipilih,inventaris sumber belajar lain yang mungkin dapat digunakan.

Hermawan dan Resmini,Mamat S,B,dkk mengemukakan dalam menyusun RPP yaitu (1)menetapkan mata pelajaran yang akan dipadukan (2)Menetapkan kompetensi dasar yang sama dalam setiap mata pelajaran, (3) menetapkan hasil belajar dan indikator pada setiap mata pelajaran,(4)menetapkan tema (5)memetakkan keterhubungan kompetensi dasar dengan tema pemersatu,(6) menyusun silabus pembelajaran tematik,dan (7) menyusun satuan pembelajaran(RPP) tematik. Hernawan dan Resmini,Mamat S,B memaknai bahwa komponen menyusun perencanaan meliputi menetapkan : mapel,kompetensi dasar,indikator,dan tema,menyusun silabus. Relevansi penelitian ini adalah terletak pada penyusunan Komponen RPP dan Silabus pembelajaran
Perencanaan pembelajaran tematik kurikulum 2013 disusun oleh guru secara mandiri, sesuai dengan kurikulum 2013,menggunakan model PAKEM dengan pendekatan kontektual. Sa'dun Akbar,dkk,2016,menemukan berbagai permasalahan yang diantaranya : guru kurang mengembangkan proses pembelajaran karena kurangnya sosialisasi buku pegangan guru sebagai faktor penentu dalam pengaplikasian buku ajar,pembelajaran yang dilakukan cenderung hanya mengacu pada buku guru,penjelasan materi dirasakan siswa kurang detail,contoh cara pengerjaan soal juga membuat siswa merasa bingung,siswa merasa bosan dan kurang tertarik dengan buku ajar. Hasil penelitian Akbar,dkk menerangkan bahwa keberhasilan implemetasi kurikulum dalam perencanaan pembelajaran dapat ditunjang dengan alat dan media pembelajaran. Relevansi penelitian ini terletak pada implementasi kurikulum. Perencanaan pembelajaran tematik di SD N 4 Purwodadi menggunakan model dan metode pembelajaran. Abdul Majid (2013 :17) mengemukakan bahwa perencanaan dapat diartikan sebagai proses penyusunan materi pelajaran,penggunaan media pengajaran,penggunaan pendekatan,metode pengajaran,dan penilaian dalam sutu alokasi waktu yang akan dilaksanakan pada masa tertentu untuk mencapai tujuan yang telah ditentukan. Hasil penelitian Abdul Majid menerangkan bahwa keberhasilan dalam proses pembelajaran ditunjang pada perencanaan pembelajaran yang disusun secara sestimatisdan efisien akan materi, media,pendekatan, metode,penilaian,alokasi waktu,dan tujuan.Relevansi penelitian ini terletak pada komponen perencanaan pelaksanaan pembelajaran tematik. Hasil observasi terhadap RPP yang dilaksanakan oleh peneliti dan Kepala Sekolah dapat dilihat pada tabel 4.1. 
Tabel 1. Hasil Observasi Perencanaan Pembelajaran

\begin{tabular}{|c|c|c|c|c|c|}
\hline \multirow[b]{2}{*}{ No } & \multirow[b]{2}{*}{ Indikator } & \multicolumn{2}{|c|}{ Kepala sekolah } & \multicolumn{2}{|c|}{ Peneliti } \\
\hline & & Sesuai & $\begin{array}{l}\text { Kurang } \\
\text { sesuai }\end{array}$ & Sesuai & $\begin{array}{l}\text { Kurang } \\
\text { Sesuai }\end{array}$ \\
\hline $\mathbf{1}$ & Identitas Sekolah & $\mathbf{v}$ & - & $\mathbf{v}$ & - \\
\hline 2 & Identitas pelajaran & $\mathbf{v}$ & - & $\mathbf{v}$ & - \\
\hline 3 & Kelas/s emester & $\mathbf{v}$ & - & $\mathbf{v}$ & - \\
\hline 4 & Materi Pokok & $\mathbf{v}$ & - & $\mathbf{v}$ & - \\
\hline 5 & Alokasi Waktu & $\mathbf{v}$ & - & $\mathbf{v}$ & - \\
\hline 6 & kompetensi Inti (KI) & $\mathbf{v}$ & - & $\mathbf{v}$ & - \\
\hline \multirow[t]{2}{*}{7} & Kompetensi das ar (KD) dan indikator & $\mathbf{v}$ & - & $\mathbf{v}$ & - \\
\hline & pencapaian kompetensi & & & & \\
\hline 8 & Tujuan pembelajaran & $\mathbf{v}$ & - & $\mathbf{v}$ & - \\
\hline 9 & Materi Pembelajaran & $\mathbf{v}$ & - & $\mathbf{v}$ & - \\
\hline 10 & Metode & $\mathbf{v}$ & - & $\mathbf{v}$ & - \\
\hline 11 & Media,alat dan s umber belajar & $\mathbf{v}$ & - & $\mathbf{v}$ & - \\
\hline 12 & Langkah -langkah kegiatan & $\mathbf{v}$ & - & $\mathbf{v}$ & - \\
\hline \multirow[t]{4}{*}{13} & Penilaian & $\mathbf{v}$ & - & $\mathbf{v}$ & - \\
\hline & Skor & 13 & & 13 & - \\
\hline & Nilai & 100 & & 100 & \\
\hline & Kategori & Sangat baik & & Sangat Baik & \\
\hline
\end{tabular}

2. Pelaksanaan pembelajaran tematik kelas V SD Negeri 4 Purwodadi kecamatan Purwodadi kabupaten Grobogan.

Pelaksanaan pembelajaran tematik di SD Negeri 4 Purwodadi terdiri dari tiga tahapan kegiatan yakni :kegiatan pendahuluan,kegiatan inti, dan kegiatan penutup. Menurut Mamat S.B, kegiatan pendahuluan atau pembukaan merupakan kegiatan untuk apersepsi. Kegiatan Inti adalah proses pembelajaran untuk mencapai KD yang dilakukan secara interaktif, inspiratif, menyenangkan, menantang, memotivasi siswa untuk berpartisipasi aktif. Kegiatan Penutup sebagai akhir dari pembelajaran guru bersama siswa menyimpulkan materi dan refleksi,dengan diajukan test dalam bentuk lisan maupun tertulis . Mamat S.B,memberi makna bahwa pelaksanaan pembelajaran melalui tiga tahap yaitu kegiatan pendahuluan,Kegiatan Inti,dan kegiatan Penutup. Relevansi penelitian ini adalah sama sama dalam pelaksanaan pembelajaran melalui tiga tahap yaitu kegiatan Pendahuluan,kegiatan Inti,dan kegiatan Penutup.Hal ini menunjukkan bahwa pelaksanaan pembelajaran Tematik di SD Negeri 4 Purwodadi sudah sesuai dengan RPP dalam kurikulum 2013
Dursun (2010) dalam artikelnya berjudul Using a Thematic TeachingApproach based on pupil's Skill and interest in social studies Teaching mengkaji bagaimana guru-guru di bidang ilmu sosial memperkenalkan aktivitas yang berorientasi pada siswa dalam ruang kelas. Penelitian menjelaskan bagaimana para siswa dapat menggunakan antusiasme mereka, ketertarikan dan keterampilan mereka dalam memahami dan mencerna materi-materi yang disampaikan di ruang kelas.Penelitian ini juga mengungkapkan bahwa pengetahuan dan keahlian para guru berkaitan dengan latar belakang akademik dan profesional mereka memiliki pengaruh yang sangat besar terhadap gaya mereka mengajar. Secara garis besar, penelitian ini berhasil mengungkapkan kelebihan-kelebihan dari teknik pembelajaran tematik yang didasarkan pada keterampilan siswa, baik dalam teori maupun praktik. Dursun memaknai bahwa keberhasilan dalam pelaksanaan pembelajaran tergantung kepada guru profesional yang dimiliki.Relevansi penelitian ini terletak pada pelaksanaan pembelajaran model PAKEM.

Pembelajaran tematik di Sekolah Dasar (Sa'dun Akbar, dkk, 2016: 2).Model pembelajaran yang diterapkan oleh guru kelas V SD Negeri 4 Purwodadi kecamatan Purwodadi adalah Model Pembelajaran 
PAKEM sedangkan metode pembelajaran meliputi : Diskusi kelompok,Ceramah,dan Penugasan.Guru menggunakan metode tersebut karaen sesuai dengan karakteristik pembelajaran Tematik yang memerlukan diskusi dalam belajar kelompok.Model pembelajaran tersebut disebut pembelajaran aktif karena bila dipraktekkan memungkinkan peserta didik belajar secara aktif sehingga proses belajarnya optimal.Hal ini sesuai penelitian abdullah (2013)

Abdullah (2013) dalam penelitiannya menjelaskan pendekatan tematik adalah salah satu strategi pembelajaran yang menggunakan tema-tema tertentu untuk menciptakan proses pembelajaran yang aktif, menarik dan bermakna. Penelitian ini berusaha untuk mengidentifikasi pemahaman dan praktik yang dilakukan para guru terhadap pendekatan tematik menggunakan istrumen kuisioner.Penelitian ini menemukan bahwa ada hubungan signifikan antara tingkat pemahaman guru dengan pendekatan tematik yang dilakukan guru secara konstan dan terus-menerus. Semakin banyak pemahaman guru mengenai proses pembelajaran tematik, maka semakin baik penyampaian dan pemahaman guru dalam berkomunikasi dengan siswa di kelas. Abdullah menerangkan bahwapendekatan tematik merupakan strategi pembelajaran yang menggunakan tema untuk menciptakan proses pembelajaran yang aktif,menarik,menyenangkan Persamaan penelitian Abdullah dengan penelitian ini yaitu menciptakan proses pembelajaran yang aktif,menarik dan bermakna. Sedangkan dari observasi kegiatan pelaksanaan pembelajarn diperoleh data seperti pada tabel 4.2.

Tabel 2. Pelaksanaan pembelajaran

\begin{tabular}{|c|c|c|c|c|}
\hline \multirow[t]{2}{*}{ No } & \multirow[t]{2}{*}{ Aspek Pengamatan } & \multicolumn{3}{|c|}{ Skor Observer } \\
\hline & & Peneliti & Kepala Sekolah & Rata-rata \\
\hline & A.KEGIATAN AWAL & & & \\
\hline 1 & Membuka pelajaran dengan salam & 4 & 4 & 4 \\
\hline 2 & Guru memberi apersepsi dan motivasi & 3 & 3 & 3 \\
\hline \multirow[t]{2}{*}{3} & Guru menyampaikan tujuan pembelajaran & 4 & 4 & 4 \\
\hline & B KEGIATAN INTI & & & \\
\hline 1 & Guru menguasai materi & 4 & 4 & 4 \\
\hline 2 & Guru mengelola kelas dengan baik & 3 & 3 & 3 \\
\hline 3 & Metode/pendekatan bervariasi & 4 & 4 & 4 \\
\hline 4 & guru menggunakan media yang sesuai & 4 & 3 & 3.5 \\
\hline 5 & guru berperan sebagai fasilitator & 3 & 3 & 3 \\
\hline 6 & Berbahasa yang baik dan benar & 3 & 3 & 3 \\
\hline \multirow[t]{2}{*}{7} & Guru mendorong siswa memanfaatkan teknologi & 3 & 4 & 3.5 \\
\hline & informasi & & & \\
\hline 8 & Siswa aktif dalam pembelajaran & 3 & 3 & 3 \\
\hline 9 & Siswa tampakceria dalam pembelajaran & 4 & 4 & 4 \\
\hline 10 & ada penilaian untuk pencapaian kompetensi & 4 & 3 & 3.5 \\
\hline \multirow[t]{3}{*}{11} & Pembelajaran selesai tepat waktu & 3 & 4 & 3.5 \\
\hline & C.KEGIATAN PENUTUP & & & \\
\hline & Guru membimbing peserta didik untuk & & & \\
\hline 1 & Membuat simpulan & 4 & 3 & 3 \\
\hline \multirow[t]{4}{*}{2} & Guru memberi tugas untuk kegiatan berikutnya & 3 & 3 & 3 \\
\hline & Jumlah & 56 & 55 & 55.5 \\
\hline & Presentase Skor & 87.5 & 85.94 & 86.72 \\
\hline & Kategori & Swangat ba & Sangat baik & Sangat Baik \\
\hline
\end{tabular}


3. Evaluasi Pembelajaran Tematik kelas V SD Negeri 4 Purwodadi Kecamatan Purwodadi Kabupaten Grobogan.

Pelaksanaan evaluasi di $\quad$ SD $\quad \mathrm{N} \quad 4$ Purwodadi kec Purwodadi kab Grobogan menggunakan penilaian autentik berbasis proses. Sudjana (2010 :59) mengemukakan evaluasi dalam enam jenis kegiatan yakni: menentukan tujuan Evaluasi,menentukan aspek yang dinilai,menentukan tekhnik evaluasi,menyusun alat ukur,menetukan tolok ukur,dan menentukan frekuensi dari kegiatan evaluasi. Sudjana menerangkan bahwa keberhasilan evaluasi pembelajaran tematik terletak pada jenis kegiatan evaluasi menyusun,mengatur,mengolah, menganalisis,dan menyimpulkan.Relevansi penelitian ini terletak pada fokus pelaksanaan evaluasi berdasarkan pada penilaian autentik berbasis proses.

Guru SD Negeri 4 Purwodadi kecamatan Purwodadi kabupaten Grobogan menggunakan kretiria ketuntasan penilaian berdasarkan acuan kretirea yaitu menekankan pada penilaian proses, menggunakankriteria ketuntasan penilaian berdasarkan Acuan kriteria, Kurikulum 2013 Kriteria Ketuntasan Minimal ditetapkan oleh satuan pendidikan berdasarkan keputusan musyawarah guru.

Nilai pengetahuan SD N 4 Purwodadi dilaksanakan dengan tes tulis dan tes lisan, nilai keterampilanmenggunakanaspek kinerja.Akbar (2007:17) menjelaskan tentang teknik evaluasi pada pembelajaran terpadu hendaknya bersifat komprehensif yaitu meliputi proses dan hasil pembelajaran tematik dengan menggunakan teknik tes maupun non tes.Pada pembelajaran tematik diperoleh nilai pengetahuan, keterampilan dan sikap. Akbar menerangkan bahwa evaluasi pembelajaran tematik menggunakan teknis tes dan non tes.dan diperoleh dari nilai Pengetahuan,keterampilan dan Sikap. Relevansi penelitian ini terletak pada Kognitif (Pengetahuan),afektif (sikap) dan Psikomotor(ketrampilan )

Hasil test nilai pengetahuan kelas V SD N 4 Purwodadi yaitu diperoleh hasil rata -rata nilai mata pelajaran IPA 83.57 dan 45 siswa yang tuntas atau mencapai $91.84 \%$, Bahasa Indonesia dengan nilai rata -rata 89.90 dan 43 siswa telah tuntas atau mencapai $87.76 \%$ sedangkan matematika dengan nilai rata -rata 72.04 dan 42 siswa yang tuntas atau mencapai $85.71 \%$. Hasil penelitian sesuai dengan penelitian Wilujeng (2014) Hasil penelitian menunjukkan ada peningkatan hasil belajar $11,25 \%$ dari $64,29 \%$ pada siklus I naik menjadi $85,71 \%$ pada siklus II. Selain itu, hasil penelitian juga menunjukkan adanya peningkatan aktivitas siswa dalam kegiatan pembelajaran.

Hasil penelitian pengelolaan penilaian pengetahuan pembelajaran tematik SD N4 Purwodadi kelas Vdapat dilihatseperti pada tabel 4.3

Tabel.3 Hasil Penilaian Pengetahuan

\begin{tabular}{|c|c|c|c|c|c|}
\hline \multirow{3}{*}{ No } & \multirow{3}{*}{ Jenis Tagihan } & \multicolumn{4}{|c|}{ Nilai } \\
\hline & & IPA & Bahasa Indonesia & Matematika & Rata-rata \\
\hline & & KKM=71 & KKM=71 & KKM=71 & \\
\hline 1 & Nialai Tertinggi & 100 & 100 & 100 & 100 \\
\hline 2 & Nilai Terendah & 70 & 70 & 25 & 55 \\
\hline 3 & Jumlah & 4095 & 4405 & 3530 & 4010 \\
\hline 4 & Rata-rata & 83.57 & 89.90 & 72.04 & 81.84 \\
\hline 5 & Jumlah siswa yang tuntas & 45 & 43 & 42 & 43.33 \\
\hline 6 & Jumlah siswa yang belum tuntas & 4 & 6 & 7 & 5.67 \\
\hline 6 & Presentase Ketuntasan & 91.84 & 87.76 & 85.71 & 88.44 \\
\hline
\end{tabular}

Hasil penilaian ketrampilan SD N 4 diperoleh skor nilai rata - rata dari Kepala Purwodadi kelas V berdasarkan observasi Sekolah 3.2 dalam kategori Baik, skor nilai 
rata - rata dari peneliti 3.4 dalam kategori Baik dan skor nilai rata - rata dari kedua observer 3.3 dalam kategori Baik
Hasil penilaian ketrampilanSD $\mathrm{N} 4$ Purwodadi kelas $\mathrm{V}$ dari observasi dapat dilihat pada tabel 4.4

Tabel 4 Hasil Penilaian Ketrampilan

\begin{tabular}{|c|c|c|c|c|c|}
\hline \multirow{3}{*}{ No } & \multirow{3}{*}{ Indikator Penilaian } & \multicolumn{4}{|c|}{ Observer } \\
\hline & & Kepala & Peneliti & Jumlah & Rata-rata \\
\hline & & Sekolah & & & \\
\hline 1 & Memilah macam-macam organisme & 3 & 3 & 6 & 3 \\
\hline 2 & Menghitung jumlah rantai makanan & 4 & 4 & 8 & 4 \\
\hline \multirow[t]{2}{*}{3} & Menulis kembali urutan rantai & 3 & 4 & 7 & 3.5 \\
\hline & makanan & & & & \\
\hline 4 & Membuat piramida makanan & 3 & 3 & 6 & 3 \\
\hline 5 & Membuat urutan aliran energi & 3 & 3 & 6 & 3 \\
\hline \multirow[t]{3}{*}{6} & Jumlah & 16 & 17 & 33 & 16.5 \\
\hline & Rata-rata & 3.2 & 3.4 & & 3.3 \\
\hline & Kategori & Baik & Baik & & Baik \\
\hline
\end{tabular}

Hasil Perolehan SikapSD N 4 Purwodadi skor rata - rata untuk aktif dalam kelompok memperoleh rata -rata 3.33 dalam kategori $\mathrm{B}$, untuk indicator bersedia memecahkan masalah dengan berdiskusi memperoleh rata - rata skor 3.67 dalam kategori $\mathrm{A}$, untuk indikator memusatkan perhatian pada tujuan kelompok memperoleh rata -rata skor 3.33 dalam kategori B dan untuk indicator mendorong orang lain bekerjasama demi tujuan kelompok memperoleh skor 3.67 dalam kategori A. Hasil ini sesuai dengan pendapat (Muslich, 2007:89) Penilaian sikap sebagai penilaian terhadap perilaku dan keyakinan siswa terhadap suatu objek

Hasil penilaian sikap SD N 4 Purwodadi kelas V dapat dilihat pada tabel 4.5 di bawah ini

Tabel 5. Hasil Penilaian Sikap

\begin{tabular}{|c|c|c|c|c|c|}
\hline \multirow{3}{*}{ No } & \multirow{3}{*}{ Indikator Penilaian } & \multicolumn{4}{|c|}{ Observer } \\
\hline & & Guru & Peneliti & Kepala & Rata-rata \\
\hline & & & & Sekolah & \\
\hline 1 & Aktif dalam kelompok & 3 & 4 & 3 & 3.33 \\
\hline \multirow[t]{2}{*}{2} & Bersedia memecahkan masalah & 4 & 3 & 4 & 3.67 \\
\hline & dengan berdiskusi & & & & \\
\hline \multirow[t]{2}{*}{3} & Memusatkan perhatian pada tujuan & 4 & 3 & 4 & 3.67 \\
\hline & kelompok & & & & \\
\hline \multirow[t]{4}{*}{4} & Mendorong orang lain untuk bekerja & 4 & 4 & 3 & 3.67 \\
\hline & samademi tujuan kelompok & & & & \\
\hline & Rata-rata & 3.75 & 3.5 & 3.5 & 3.58 \\
\hline & Kategori & Sangat Baik & SangatBaik & Sangat Baik & Sangat Baik \\
\hline
\end{tabular}

Prestasi belajar siswa SD Negeri 4 Purwodadi kelas V kecamatan Purwodadi kabupaten Grobogan menunjukkan kemampuan sikap ,pengetahuan dan ketrampilan berdasarkan evaluasi.dan berkesinambungan

Hajar (2013 :267) menjelaskan bahwa penilaian pembelajaran tematik adalah usaha yang dilakukan oleh pihak sekolah atau para guru untuk mendapatkan berbagai informasi secara berkala,berkesinambungan,dan menyeluruh tentang proses dan hasil dari pertumbuhan dan perkembangan yang telah dicapai oleh para peserta didik .Hajar menerangkan bahwa penilaian pembelajaran tematik dilaksanakan secara berkala dan 
berkesinambungan. Relevansi penelitian ini terletak pada pelaksanaan evaluasi dilakukan secara berkala dan berkesinambungan.

Menurut Blom dalam Sudjana (2010 :22) menyatakan bahwa hasil belajar dikelompokkan menjadi tiga domain, yaitu kognitif ,afektif dan psikomotor. Domain kognitif memiliki enam jenjang kemampuan yakni Pengetahuan, pemahaman, penerapan, analisis, sintesis, dan evaluasi. Domain Afektif memiliki empat jenjang kemampuan yakni kemampuan menerima, menanggapi, menilai, dan organisasi. Domain psikomotor memilik kemampuan bertindak. Penilaian ini dinamakan juga dengan penilaian autentik. Sudjana menerangkan bahwa hasil belajar dikelompokkan menjadi tiga ranah yaitu ranah kognitif melalui pemahaman, penerapan, analisis, sintesis dan evaluasi, ranah efektif meliputi menerima, menanggapi, menilai, dan organisasi, dan ranah psikomotorik meliputi kemapuan bertindak. Relevansi penelitian ini adalah sama sama menggunakan tiga domain yaitu Kognitif, Afektif, dan Psikomotorik.

Hasil evaluasi dalam ranah kognitif, afektif , dan psikomotor menunjukkan bahwa siswa kelas V SD Negeri 4 Purwodadi ,kecamatan Purwodadi memiliki prestasi tinggi pengetahuan, sikap dan keterampilan yang baik.Hasil wawancara dengan guru dan kepala sekolah diperoleh Penilaiannya lebih menekankan padapenilaian proses, baikpada aspek sikap,pengetahuan dan keterampilan. Guru menggunakankriteria ketuntasan penilaian berdasarkan Acuan kriteria. ketuntasan Kompetensi sikap dalam bentuk deskripsi minimal baik.nilai pengetahuan dilaksanakan dengan tes tulis dan tes lisan, nilai keterampilanmenggunakanaspek kinerja,prestasi belajar siswa menunjukkan kemampuan sikap, pengetahuan, dan keterampilan berdasarkan hasil evaluasi.

\section{Penutup}

Perencanaan pembelajaran dalam bentuk Rencana Pelaksanaan Pembelajaran (RPP) yang dibuat oleh guru kelas V SD Negeri 4Purwodadi Kecamatan Purwodadi Kabupaten Grobogan sudah sangat baik dan telah sesuai dengan karakter penyusunan RPP.

Dalam pelaksanaan pembelajaran tematik meliputi kegiatan pendahuluan memulai pembelajaran dengan orientasi, apersepsi,motivasi diteruskan menyampaikan pokokmateri dantujuanpembelajaran.kegiatan inti penyajian materi tematik menggunakan metode yang bervaritif,pembelajaran menimbulkan keceriaan siswa, pendekatan saintifik, guru sebagai fasilitator. Sedangkan untuk pengelolaan kegiatan penutup siswa bersama guru menyimpulkan pembelajaran dan melakukan refleksi.

Pelaksanaan evaluasi meliputi penilaian pengetahuan, ketrampilan dan sikap. hasil nilai pengetahuandari mata pelajaran IPA, Bahasa Indonesia dan matematika dengan nilai rata-rata 81.66dengan presentase ketuntasan $88.34 \%$. penilaian ketrampilan diperoleh skor nilai rata-rata dari Kepala Sekolah dan peneliti 3.3 dalam kategori Baik. Perolehan nilai sikap diperoleh rata-rata skor dari peneliti, guru dan Kepala Sekolah 3.3 dalam kategori Baik.

\section{Daftar Pustaka}

Ahmadi Khoiru,Amri Sofyan,2014. Pengembangandan Model Pembelajaran Tematik Di Sekolah Dasar. Bandung.Remaja Rosdakarya

Arsyad,A. 2004 . Media pembelajaran : Jakarta : PT Raja Grafindo Persada

Asrohah H, Kadir A.2015.Pembelajaran tematik. Jakarta: Rajawali Press.

Arifin, Z. 2006. Dasar-dasar penulisan karya ilmiah. Jakarta: Grasindo. 2012.Evaluasi pembelajaran : Prinsip,Teknik,Prosedur :Bandung.PT Remaja Rosdakarya 
Arikunto, Suharsimi. 2002. Prosedur penelitian: Suatu Pendekatan Praktik, Jakarta: Rineka Cipta.

Anitah, S 2008. Media pembelajaran : Surakarta : UPT Penerbitan dan Pencetakan UNS (UNS Press)

Creswell,W J.2015.Penelitian kualitatif \& desain riset : Edisi Indonesia: Pustaka Pelajar.

Djamal,M.2015. Paradigma penelitian kualitatif : Edisi Revisi.Yogyakarta : Pustaka Pelajar. 2017. Paradigma penelitian kualitatif : Yogyakarta :Penerbit Mitra Pustaka

Depdiknas. 2007. Materi sosialisasi dan pelatihan kurikulum satuan pendidikan (KTSP). Jakarta

Daryanto.2014.Pendekatan Pembelajaran Saintifik Kurikulum 2013. Yogyakarta.Gava Media.

Hesty.(2008). "Implementasi model pembelajaran tematik untuk meningkatkankemampuan dasar siswa sekolah dasar.”Abstrak Hasil Penelitian LPMP Kepulauan Bangka Belitung. Pangkalpinang: LPMP Pangkalpinang.

Haris A,Jihad A. 2013 .Evaluasi pembelajaran : Yogyakarta : Multi Pressindo.

Irene MJA,dkk. 2016. Buku Penilaian Tema 8 Lingkungan Sahabat Kita dan Tema 9 BendaBenda di Sekitar Kita Jilid 5D untuk SD/MI Kelas 5. Jakarta.Penerbit Erlangga

Kadir Abdul,Asrohah Hannun.2015.PembelajaranTematik.Depok.Rajagrafindo Persada.

Kusaeri.2014.Acuan dan Teknik Penilaian Proses dan Hasil BelajarDalam Kurikulum 2013. Jakarta.Ar-Ruzz Media

Kunandar. 2007. Guru profesional: implementasi kurikulum tingkat satuan pendidikan (KTSP) da Persiapan Menghadapi Sertifikasi Guru. Jakarta: PT RajaGrafindo Persada.

Majid A. 2007. Perencanaan pembelajaran. Bandung: PT Remaja Rosdakarya.

2014.Pembelajaran tematik terpadu.Bandung : PT Remaja Rosdakarya.

Moleong, Lexy J. 2005. Metodologi penelitian kualitatif. Bandung: Remaja Rosdakarya. .2016 Metodologo Penelitian Kualitatif.Bandung.Remaja Rosdakarya.

Majid dan Rochman.2015. PendekatanIlmiah dalam Implementasi Kurikulum 2013.Bandung. Remaja Rosdakarya.

Nasution. 2005. Asas-asas kurikulum. Jakarta: Bumi Aksara.

Prastowo A.2016.Pengembangan Bahan ajar tematik : Tinjauan Teoritis dan Praktik. Jakarta : Kencana

.2014. Pengembangan Bahan Ajar Tematik Tinjauan Teoritis Dan Praktik. Jakarta.FajarIntr Pratama Mandiri.

.2013. Pengembangan bahan Ajar Tematik : Yogyakarta.Penerbit DIVA Press

Purwanto, M. Ngalim. 1995. Ilmu pendidikan: teori dan praktik. Bandung: Remaja Rosdakarya.

Sarwono, J.2006.Metode penelitian kuantitatif dan kualitatif :Yogyakarta

Penerbit Graha Ilmu.

Sanjaya, Wina. 2008.Strategi pembelajaran.Jakarta: Kencana Prenada Media.

Suprihatiningrum,J.2016. Strategi pembelajaran : Teori \& Aplikasi :Yogyakarta :AR-RUZZ 
MEDIA.

Sarwiji Suwandi. (2010). Model assesment dalam pembelajaran. Surakarta: Yuma Pustaka.

Savage, Tom V. \& Armstrong, David G. (1996).Effective teaching in elementary social studies. New Jersey: A Simon \& Schuster Company.

Semiawan. 1992.Pendekatan ketrampilan proses. Jakarta: Gramedia Pustaka Utama.

Settlage, John \& Southerland, Sherry A. (2007).Teaching science teaching science to every child: using culture as a starting point. New York: Taylor \& Francis Group.

Sudjana,Nana, 2004. Penilaian proses hasil belajar mengajar. Bandung: Remaja Rosda Karya. Sugiono. 2012. Metode penelitian kuantitatif kualitatif dan R\&D : Bandung .Penerbit Alfabeta .2016 . Metode Penelitian Kualitatif,KuantitatifDan R\&D.Bandung.Alfabeta.

Sutama.2012Metode Penelitian pendidikan kuantitatif kuanlitatif,PTK,R\&D

Surakarta : Fairus Media

Triyono.2013. Metodologi penelitian pendidikan. Yogyakarta : Penerbit Ombak 